\title{
Efficacy of smear layer removal by cavity cleaning solutions: an atomic force microscopy study
}

\author{
Eficácia da remoção da lama dentinária por soluções de limpeza \\ cavitária: estudo de microscopia de força atômica
}

\begin{abstract}
Purpose: To evaluate the efficacy of smear layer removal by cavity cleaning agents by the use of atomic force microscopy (AFM).

Methods: Five intact human third molars were sectioned in the coronal portion to obtain dentin disks, which were ground with 600-grit abrasive paper for $10 \mathrm{~s}$. Serial longitudinal sections were made perpendicular to each other to create four specimens, from each tooth. The specimens were divided into four treatment groups: $\mathrm{Gl}, 2 \%$ chlorhexidine; Gll, calcium hydroxide solution; GIII, 1.23\% fluoride solution; and GIV, 37\% phosphoric acid. The solutions were applied with a brush for $60 \mathrm{~s}$, with the exception of the $37 \%$ phosphoric acid, which was applied for $15 \mathrm{~s}$ and rinsed with distilled water for $60 \mathrm{~s}$. The specimens were examined by AFM.

Results: All of the specimens in GI and Gll showed $100 \%$ of the dentin tubules obliterated by the smear layer. However, all of the specimens in GIII and GIV showed 0\% of the dentin tubules obliterated by the smear layer.

Conclusion: The $1.23 \%$ fluoride solution was effective in removing the smear layer and can be used as a cavity cleanser.
\end{abstract}

Key words: Smear layer; chlorhexidine; sodium fluoride

\section{Resumo}

Objetivo: Avaliar a eficácia da remoção de lama dentinária por agentes de limpeza cavitária através da análise de microscopia de força atômica (MFA).

Metodologia: Cinco terceiros molares humanos hígidos foram seccionados transversalmente na porção coronária, obtendo discos de dentina de $2 \mathrm{~mm}$, que foram desgastados com lixas de granulação 600, por 10 s. Foram feitos cortes seriados longitudinais e perpendiculares entre si, obtendo-se quarto espécimes de cada dente. Os espécimes foram divididos em 4 grupos: Gl- clorexidina a 2\%; Gll- água de hidróxido de cálcio; GIII- solução fluoretada a 1,23\%; GIV - ácido fosfórico 37\%. As soluções foram aplicadas com pincel por 60 s, com exceção do ácido fosfórico que foi aplicado por $15 \mathrm{~s}$ e lavado com água destilada pelo mesmo tempo. Os espécimes foram analisados por MFA.

Resultados: Todos os espécimes de GI e Gll apresentaram 100 \% dos túbulos dentinários obliterados por lama dentinária. Os espécimes de GIII e GIV apresentaram 0 \% dos túbulos obliterados por lama dentinária.

Conclusão: A solução de fluoretada a 1,23 \% foi eficiente na remoção de lama dentinária, podendo ser empregada na limpeza de cavidades.

Palavras-chaves: Camada de esfregaço; clorexidina; fluoreto de sódio

\author{
Jiovanne Rabelo Neri a \\ Vanara Florêncio Passos a \\ Felipe Bandeira de Alencar Viana a \\ Lidiany Karla Azevedo Rodrigues a \\ Vicente de Paulo Aragão Saboia a \\ Sérgio Lima Santiago a
}

\begin{abstract}
a Department of Restorative Dentistry, Faculty of Pharmacy, Dentistry and Nursing, Federal University of Ceara, Fortaleza, CE, Brazil
\end{abstract}

\author{
Correspondence: \\ Sérgio Lima Santiago \\ Rua Monsenhor Furtado \\ Fortaleza, CE - Brazi \\ 60430-350 \\ E-mail: sergiosantiago@yahoo.com
}

Received: August 26, 2011

Accepted: September 23, 2011

Conflict of Interest Statement: The authors state that there are no financial and personal conflicts of interest that could have inappropriately influenced their work.

Copyright: (C) 2011 Neri et al.; licensee EDIPUCRS This is an Open Access article distributed under the terms of the Creative Commons AttributionNoncommercial-No Derivative Works 3.0 Unported License. 


\section{Introduction}

The mechanical preparation of a cavity with rotating or manual instruments produces a semi-porous layer formed by small particles from the cutting debris; the thickness, composition and morphology of the smear layer depends on the instrumentation and dentin location from which it was created (1). However, this layer adheres firmly to the dentin surface and can interfere in resin-dentin bonding (2).

The development of self-etching primers raised the possibility of incorporating the original smear layers into hybrid layers (2). Acidic monomers of self-etching adhesives partially dissolve and infiltrate the smear layer and hydroxyapatite to generate a hybrid layer (3). However, there is some concern that self-etching primers may not be able to penetrate through thick smear layers (4). The acidity of the primer could also be buffered by the mineral components of the smear layer to the extent that the potential for primer penetration into the underlying sound dentin might be reduced, resulting in gaps in adhesive restorations (2). Because of these considerations, the treatment of the smear layer can be an important influence on the good performance of restorations (1).

Different kinds of chemical solutions have been employed to clean cavities and remove the smear layer for restorative procedures $(5,6)$. When dentin is etched with acid solutions, such as phosphoric acid, the smear layer and smear plug are completely removed and the surface of the dentin is morphologically changed (7). Because non- or slightly-demineralizing agents, e.g., chlorhexidine digluconate, calcium hydroxide solution and some fluoride solutions, act by the simple mechanical action of washing and scrubbing, they also may result in partial removal of the smear layer (8).

To analyze the process of smear layer removal, it is necessary to monitor the dentin surface after application of the cleaning materials (9). The atomic force microscope (AFM) is a member of the scanning probe microscopy family of instruments, which also includes the scanning tunneling microscope (10). The AFM offers the opportunity to image the 3-dimensional surface topography of biological specimens with high spatial resolution under a wide variety of conditions. These conditions include exposure to air, water and other storage solutions at elevated or reduced temperatures (11). Due to its mechanism of image formation, there is no need for staining, dehydration, thin film covering or a vacuum environment. Hence, dental tissues, such as dentin, can be measured directly (12). However, there are only a few studies that employ AFM to investigate the removal of the dentin smear layer $(9,12)$.

The aim of this in vitro study was to evaluate the efficacy of smear layer removal by different cavity cleaning agents, $2 \%$ chlorhexidine digluconate, calcium hydroxide solution, $1.23 \%$ fluoride solution and $37 \%$ phosphoric acid (positive control), through analysis by AFM. The null hypothesis tested was that there would be no difference in the effectiveness of smear layer removal among the cleaning solutions.

\section{Methods}

Five unerupted, caries-free third molars were collected after the patients' informed consent had been obtained under a protocol reviewed and approved by the local Internal Review Board (116/2008). The selected teeth were stored in $0.01 \%$ thymol solution and used within one month after extraction. The occlusal enamel and deep dentin were removed by cutting two parallel sections at right angles to the long axis of the tooth using a slow-speed saw on a Labcut 1010 machine (Extec Corp, Enfield, CT, USA) under water cooling at $300 \mathrm{rpm}$ to obtain 2-mm-thick disks of midcoronal dentin. Additionally, all the disks were longitudinally sectioned in both the $\mathrm{x}$ and $\mathrm{y}$ directions across the center of the dentin surface resulting in four dentin specimens from each tooth. All the specimens were ground with 600 -grit silicon carbide paper $(\mathrm{SiC})$ for 60 seconds to create a uniform smear layer.

The specimens were randomly allocated into four groups $(n=5)$ by Excel software (Excel 2003, Microsoft Corporation, One Microsoft Way, Redmond, WA, USA) according to the following treatment solutions: GI, $2 \%$ chlorhexidine digluconate; GII, calcium hydroxide solution; GIII, 1.23\% fluoride solution; and GIV, 37\% phosphoric acid solution as a positive control (Table 1). The cavity cleaning solutions were applied with a micropipette $(50 \mu \mathrm{l})$ and agitated on the entire dentin surface with an applicator microbrush (KG Brush; KG Sorensen, Cotia, SP, Brazil). All the solutions were rubbed for 60 seconds except for phosphoric acid, which rubbed for 15 seconds and was rinsed for 60 seconds with distilled water. Excess of all solutions were removed with absorbent paper.

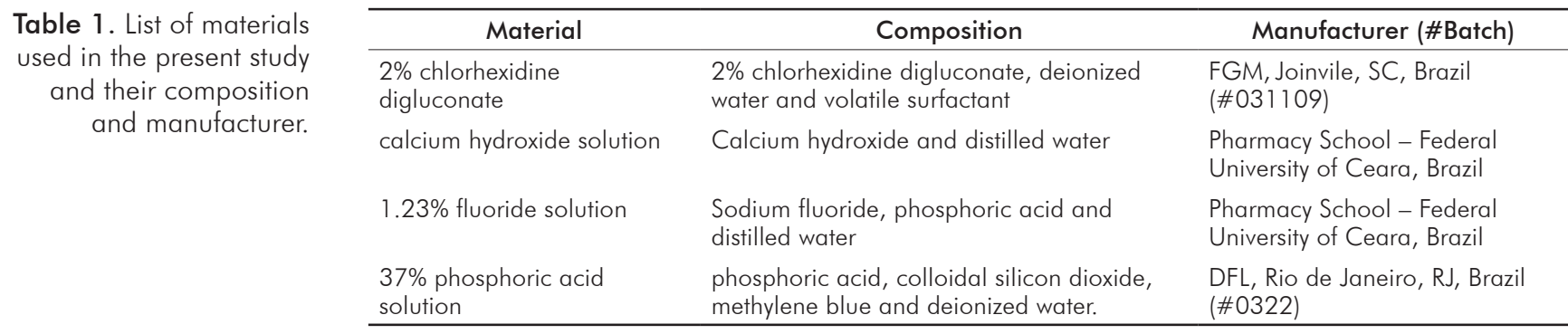


After treatment, the specimens were fixed in a metallic device using double-sided tape (3M do Brasil Ltda, São Paulo, SP, Brazil). Following this, measurements were collected with an AFM (Nanoscopy IIIa AFM - Digital Instruments, Santa Barbara, CA, USA) using tapping mode. Tapping mode operates by scanning across the sample surface using pyramidal tips of $\mathrm{Si}_{3} \mathrm{~N}_{4}$ attached to the end of a vibrating cantilever so that it is in intermittent contact with the surface. The cantilever amplitude is maintained constant by altering the vertical position of the piezoelectric scanner. Images were recorded at a slow scan rate $(1 \mathrm{~Hz})$. Each dentin disk was scanned across the central area. The scanning area was $50 \times 50 \mu \mathrm{m}^{2}$.

\section{Results}

GI and GII micrographs showed dentin surfaces with dentin tubules completely covered by the smear layer, and ripples created by the action of $\mathrm{SiC}$ abrasives were visible (Fig. 1 and 2). However, in GIII micrographs, it is possible to clearly identify the openings of the dentin tubules, indicating that the smear layer was completely removed from the dentin surfaces. In GIV micrographs (Fig. 1 and 2), the presence of peaks and valleys formed from the expansion in diameter of the opening of the dentin tubules was also visible.

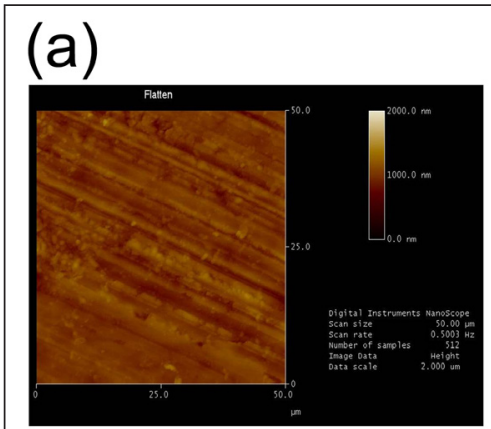

(c)

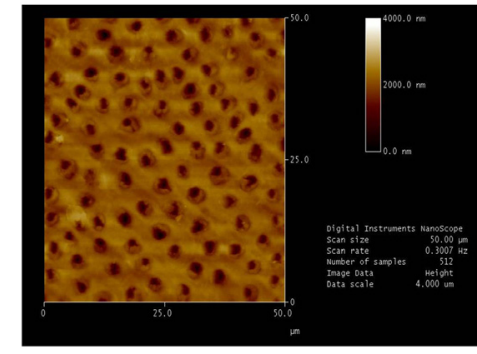

(b)

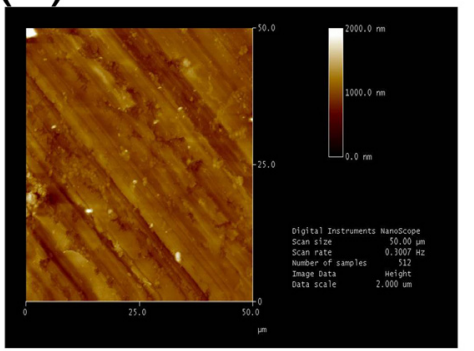

(d)

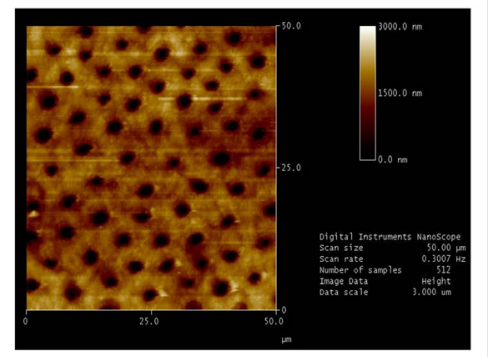

Fig. 1. AFM micrographs of the top of human dentin across a $50 \mu \mathrm{m} \times 50 \mu \mathrm{m}$ scan area:

(a) $2 \%$ chlorhexidine digluconate;

(b) calcium hydroxide solution;

(c) $1.23 \%$ fluoride solution;

(d) $37 \%$ phosphoric acid solution.
Fig. 2. Three-dimensional AFM micrographs of human dentin across a $50 \mu \mathrm{m} \times 50 \mu \mathrm{m}$ scan area:

(a) $2 \%$ chlorhexidine digluconate; (b) calcium hydroxide solution; (c) $1.23 \%$ fluoride solution; (d) $37 \%$ phosphoric acid solution.

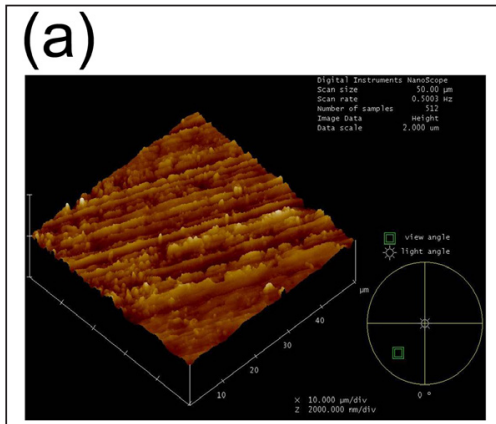

(c)

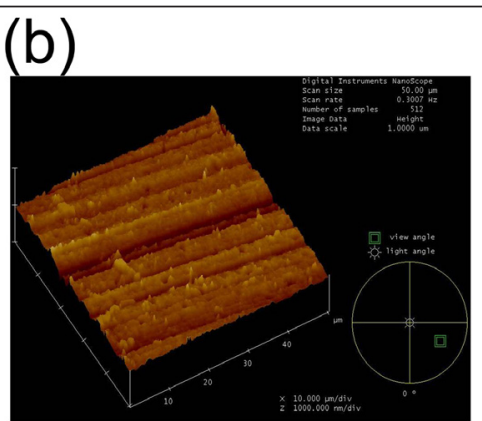

(d)
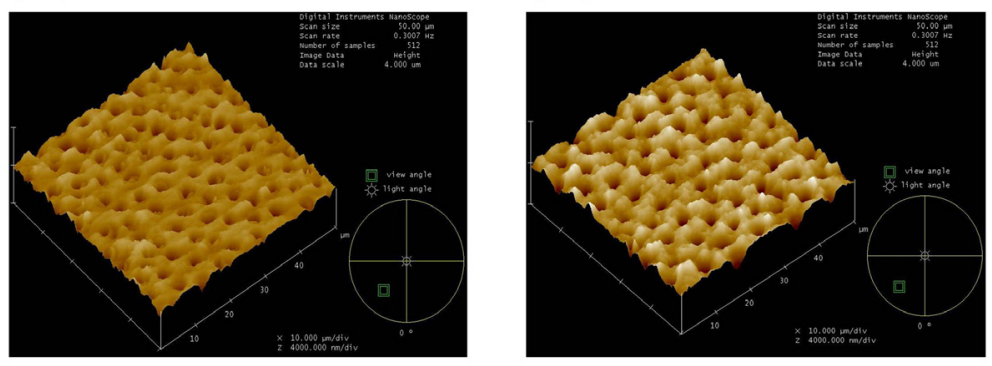
Table 2. Score distribution with regard to smear layer removal in each experimental group ( $n=5 /$ group)

\begin{tabular}{cccc}
\hline \multirow{2}{*}{ Groups s } & \multicolumn{3}{c}{ Score } \\
\cline { 2 - 4 } & A & B & C \\
(100\% of tubules obliterated) $)$ & $(50 \%$ of tubules obliterated $)$ & (0\% of tubules obliterated $)$ \\
GI & 5 & 0 & 0 \\
GIII & 5 & 0 & 0 \\
GIV & 0 & 0 & 5 \\
\hline
\end{tabular}

The results of a visual assessment of the specimens, according to the images, are presented in Table 2. The chlorhexidine digluconate and the calcium hydroxide solution did not remove the smear layer from the dentin surface, while the $1.23 \%$ fluoride solution and the $37 \%$ phosphoric acid solution completely removed the smear layer from the specimens.

\section{Discussion}

Tapping mode AFM has been used in some dental research, dealing mainly with dentin alterations, such as in hybrid layer analysis (13) and dentin demineralization effects (14). Marshall et al. (15) were pioneers in the investigation of acid etching of dentin surfaces with AFM, and recently, other studies have adopted AFM to analyze dentin surfaces rather than using scanning electron microscopy (SEM), which has been traditionally used $(9,16,17)$. The advantages of AFM are beyond the supply of high quality 3-dimensional images; this technique allows the analysis of nonconductive samples without the requirement for prior preparation, which is fundamental to analysis using SEM (12). In SEM, sample preparation is complicated and invasive, which may change the primary structure of samples. In contrast, AFM is noninvasive, and it can work in the air or in physiological conditions without causing irreversible damage to the samples (17). However, AFM also has some critical limitations. The main problems were related to sample surface height variations, and to image acquisition speed (10).

The use of non- or slightly-demineralizing agents on dentin surfaces promotes changes in the smear layer but does not expose the opening of dentin tubules (18). Luz et al. (8) observed changes in the structure of the smear layer and slight smear layer removal in specimens treated with biologic detergents when compared with air/water spray, but it was not completely removed. These results can be explained by the active methods in which the solutions were applied; it is possible that the mechanical actions of the procedures modified the results of the chemical treatments. The cleaning of the cavity with the calcium hydroxide solution or $2 \%$ chlorhexidine digluconate also did not possess the ability to remove the cutting debris responsible for the obliteration of dentin tubules, as observed in this study.

Chlorhexidine is used as a cavity cleaning agent because of its proven antibacterial properties and its substantivity (19). Previous studies have shown that the application of chlorhexidine as a cleaning agent after dentin acid etching does not promote immediate adverse effects on the adhesive bond strength between the composite and the dentin (20, 21). According to Zhou et al. (22), the use of chlorhexidine added to an adhesive primer for self-etching in two steps had no adverse effect on the bond strength to dentin tested immediately. However, Ercan et al. (23) found that the use of $2 \%$ chlorhexidine in disinfecting a cavity significantly reduces the shear strength of dentin when associated with self-etching adhesive systems. De Castro et al. (21) found that $2 \%$ chlorhexidine, applied before or after acid etching of dentin, does not affect the bond strength of composite-todentin treated with the adhesive systems Prime \& Bond NT, Single Bond or Clearfil SE Bond. Carrilho et al. (24) found that the application of chlorhexidine inhibited the action of matrix metalloproteinases (MMPs) on collagen exposed by acid etching that was not covered by the adhesive monomers, so there was a preservation of the adhesive bond strength of composite to dentin when using adhesive systems associated with total conditioning.

The results observed from the application of the $1.23 \%$ fluoride solution ( $\mathrm{pH} 3.6$ ) were similar to the $37 \%$ phosphoric acid in removing the smear layer and exposing the dentin tubules. This result can likely be attributed to the low $\mathrm{pH}$ of the solutions and the active application of these cleaning agents. However, these results were not observed in other studies involving other types of fluoride, such as $1.27 \%$ acidulated phosphate and $2 \%$ sodium fluoride; the use of these cleaning agents did not expose the dentinal tubules, although they did disorganize the smear layer $(18,25)$. The likely hypothesis for the differences among these data can be attributed to the use of fluoride in gel form, which reduces the penetration of these agents into the smear layer; the sodium fluoride used had a neutral $\mathrm{pH}$, therefore it had no demineralizing action.

According to the results from our study, the null hypothesis was rejected because there was a difference observed in the effectiveness among the cavity cleaning agents. The $1.23 \%$ fluoride solution promoted the complete removal of the smear layer, differing from the calcium hydroxide solution and the $2 \%$ chlorhexidine digluconate. However, additional studies are necessary to clarify the effects of the $1.23 \%$ fluoride solution on the bond strength of resin to dentin and immediately and after periods of artificial aging.

\section{Conclusion}

AFM is a useful alternative method to visualize changes in the microstructure of dentin after the application of cleaning agents; thus, it indicated the efficacy of sodium fluoride in removing the smear layer. 
1. Rocha Pl, Borges AB, Rodrigues JR, Arrais CAG, Giannini M. Effect of dentinal surface preparation on bond strength of self-etching adhesive systems. Braz Oral Res 2006;20:52-8

2. Tay F, Sano H, Carvalho R, Pashley D. An ultrastructural study of the influence of acidity of self-etching primers and smear layer thickness on bonding to intact dentin. J Adhes Dent 2000;2:83-98.

3. Van Meerbeek B, De Munck J, Yoshida Y, Inoue S, Vargas M, Vijay P, et al. Buonocore memorial lecture. Adhesion to enamel and dentin: current status and future challenges. Oper Dent. 2003;28:215-35.

4. Watanabe I, Saimi Y, Nakabayashi N. Effect of smear layer on bonding to ground dentinRelationship between grinding conditions and tensile bend strength. J Japanese Soc Dent Mater 1994;13:101-8.

5. Campos EA, Correr GM, Leonardi DP, Pizzatto E, Morais EC. Influence of chlorhexidine concentration on microtensile bond strength of contemporary adhesive systems. Braz Oral Res 2009;23:340-5.

6. Pisani-Proença J, Erhardt MC, Amaral R, Valandro LF, Bottino MA, Del Castillo-Salmerón $R$. Influence of different surface conditioning protocols on microtensile bond strength of self-adhesive resin cements to dentin. J Prosthet Dent 2011;105:227-35.

7. Pimenta RA, Penido CV, Cruz Rde A, Alves JB. Morphology of the dentin on primary molars after the application of phosphoric acid under different conditions. Braz Oral Res 2010;24:323-8.

8. Luz MAAC, Garone Neto N, Aranha-Chaves VE, Sobral MAP, Singer J M. Evaluation of chemical and/or mechanical treatments of the smear layer as revealed by scanning electron microscopy . a blind comparative study. Pesq Odont Bras 2000;14:101-6.

9. Batista HC, Da Silva Júnior JG, Silva MFA, Tonholo J. Atomic Force Microscopy of Removal of Dentin Smear Layers. Microsc Microanal. 2007;13:245-50.

10. De-Deus G, Reis C, Paciornik S. Critical appraisal of published smear layer - removal studies: methodological issues. Oral Surg Oral Med Oral Pathol Oral Radiol Endod $2011 ; 112: 531-43$

11. Silikas N, Watts DC, England KE, Jandt KD. Surface fine structure of treated dentine investigated with tapping mode atomic force microscopy (TMAFM). J Dent 1999;27:137-44.

12. Sanches RP, Otani C, Damião AJ, Miyakawa W. AFM characterization of bovine ename and dentine after acid-etching. Micron 2009;40:502-6.

13. Eliades $G$, Vougiouklakis $G$, Palaghias $G$. Effect of dentin primers on the morphology, molecular composition and collagen conformation of acid-demineralized dentin in situ. Dent Mater 1999; 15:310-7.

14. Watari F. In situ quantitative analysis of etching process of human teeth by atomic force microscopy. J Electron Microsc 2005;54:299-308.

15. Marshall GW Jr, Balooch M, Tench RJ, Kinney JH, Marshall SJ. Atomic force microscopy of acid effects on dentin. Dent Mater 1993;9:265-8.

16. Botta SB, Ana PA, de Sa Teixeira F, da Silveira Salvadori MC, Matos AB. Relationship between surface topography and energy density distribution of Er,Cr:YSGG beam on irradiated dentin: an atomic force microscopy study. Photomed Laser Surg 2011 ;29:261-9.

17. Ma S, Cai J, Zhan X, Wu Y. Effects of Etchant on the Nanostructure of Dentin: An Atomic Force Microscope Study. Scanning 2009;31:28-34.

18. Matos AB, Saraceni CHC, Matson E, Carvalho RCR, Pinto Junior DS. [In vitro study of several agents used in dentin surface cleaning]. RPG 1995;2:37-44.

19. Fardal O, Turnbull RS. A review of the dental literature on the use of chlorhexidine in dentistry. J Am Dent Assoc 1986;1 12:863-9.

20. El-Housseiny AA, Jamjoum $\mathrm{H}$. The effect of caries detector dyes and a cavity cleansing agent on composite resin bonding to enamel and dentin. J Clin Pediatr Dent 2000;25:57-63

21. De Castro FL, De Andrade MF, Duarte Junior SL, Vaz LG, Ahid FJ. Effect of $2 \%$ chlorhexidine on microtensile bond strength of composite to dentin. J Adhes Dent 2003:5:129-38.

22. Zhou J, Tan J, Yang X, Cheng C, Wang X, Chen L. Effect of chlorhexidine application in a self-etching adhesive on the immediate resin-dentin bond strength. J Adhes Dent 2010;1227-31.

23. Ercan E, Erdemir A, Zorba YO, Eldeniz AU, Dalli M, Ince B, et al. Effect of different cavity disinfectants on shear bond strength of composite resin to dentin. J Adhes Dent $2009 ; 11343-6$

24. Carrilho MRO, Carvalho RM, de Goes MF, di Hipólito V, Geraldeli S, Tay FR, et al Chlorhexidine Preserves Dentin Bond in vitro. J Dent Res 2007;8690-4.

25. Araújo MAJ, Rode SM, Villela LC, Gonçalves RD. [Smear layer removal: a qualitative scanning electron microscopy study]. Rev Odont Univ São Paulo 1998;1299-104. Portuguese. 